Archive for

Organic Chemistry

Arkivoc 2019, part ii, 86-98

\title{
Enantiospecific synthesis of sn-1,2-, 2,3-, and 1,3-diacylglycerols as naphthylethylurethane derivatives
}

\section{Ornelio Rosati, ${ }^{*}$ Francesca Blasi, Domenico Montesano, Diana Persia, Maria Carla Marcotullio, Bonifacio Monti, and Lina Cossignani}

Department of Pharmaceutical Sciences, University of Perugia, via del Liceo 1, 06123 Perugia, Italy Email: Ornelio.rosati@unipg.it

Dedication to Prof. Lorenzo Testaferri to commemorate his 75th birthday and to acknowledge his contribution to Organic Chemistry as a researcher and as a teacher

Received 10-15-2019

Accepted 10-31-2019

Published on line 11-07-2019

\section{Abstract}

The sn-diacylglycerols (DAGs) are important intermediates from a biological point of view. For this reason, the derivatization of DAGs with optically active protective groups represents an important strategy for their characterization. In this work a high-yielding enantiospecific synthesis of stable samples of DAGs as (S)-(1naphthyl)-ethyl urethane derivatives is reported.<smiles></smiles>

Keywords: DAGs; protective groups; enantiospecific synthesis; naphthylethyl urethane derivatives 


\section{Introduction}

In the last decades, the interest of consumers and scientific community in developing drugs and nutraceuticals from vegetable sources has grown significantly. Especially in recent years, there has been a return to natural remedies using compounds and plant extracts with relevant health properties ${ }^{1,2,3,4}$ that have been used against many diseases and illnesses. Many natural compounds, belonging to different chemical classes, have been studied and fully characterized ${ }^{5,6}$ starting from different parts of plants. ${ }^{7}$

Diacylglycerols (DAGs) are compounds that may exist in three isomeric forms two of which, sn-1,2- and sn2,3-DAGs, are optically active enantiomers, while the form of $s n-1,3-D A G s$ is optically inactive. ${ }^{8,9}$ Among these, the sn-1,2-DAGs certainly play an important role from a biological point of view, as they can be second messengers in many cellular processes, intermediates in biosynthesis and catabolism of triglycerides and in the biosynthesis of some phospholipids (phosphatidylcholine, phosphatidylethanolamine, phosphatidylserine $)^{10,11}$ and they represent important membrane modulators. ${ }^{12}$

The $s n$-DAGs are also the subject of numerous synthetic studies, with particular focus on the development of protective groups that allow the preparation of optically active glycerols. ${ }^{13,14}$ The synthesis of some digalactosyldiacylglycerols, which have antihyperlipidemic activity and other important biological activities, has also been reported. ${ }^{15}$ No less important is their role in the field of food chemistry; indeed, the determination of the relationship between $s n-1,2-, s n-2,3-$, and $s n-1,3-D A G s^{16,17}$ is an index for the evaluation of state of fresh olive oils (age and conservation methods). ${ }^{18,19,20}$ Different methods are available for the preparation of DAG-rich oils. ${ }^{21,22}$ From nutritional point of view, consumption of DAG-rich oil enhances loss of body weight and fat in comparison with consumption of a triacylglycerol control oil. 8,23,24

Various techniques that allow the isolation of the fraction containing DAGs and, subsequently, their separation in the form of suitable derivatives such as, for example, $(R)$ - or (S)-1-(1-naphthyl)-ethyl urethanes have been developed. ${ }^{25,26}$

The diastereomers character of $(R)$ - or (S)- 1-(1-naphthyl)-ethyl urethane derivatives of $s n-1,2$ - and $s n-2,3-$ DAGs makes the properties of these compounds sufficiently different to allow their separation and characterization. Indeed, $(R)$ - or (S)- 1-(1-naphthyl)-ethyl urethane moiety is usually used in order to clarify some stereochemical details of natural occurring compounds, for example to determine the absolute stereochemistry of umbraculumins $\mathrm{A}$ and $\mathrm{C}^{27}$ and an unusual DAG (i.e. archidorin), isolated from the mantle of the mollusk Archidoris tuberculate ${ }^{28}$ or to separate monoacylglycerol classes from extravirgin olive oil. ${ }^{29}$

Nuclear magnetic resonance (NMR) analysis was demonstrated to be a valuable spectroscopic technique in the field of lipid analysis, for example, to establish composition and lipid classification, to provide information on the regiospecific distribution of fatty acids in triacylglycerols (TAGs) and phospholipids and to verify the authenticity and adulteration of food products. ${ }^{30,31,32}$

In this field, very few spectroscopic data on diacylglycerol isomers and enantiomers are reported in the literature. ${ }^{33}$ In 2007 we performed a study on HPLC separation and NMR structural elucidation of sn-1,2-, 2,3-, and 1,3-diacylglycerols from olive oil derivatized as (S)-1-(1-naphthyl)-ethyl urethanes. ${ }^{34}$

To the best of our knowledge, this is the first study that reports complete mono- and two dimensional spectroscopic NMR data of the three individual classes of diacylglycerol derivatives mentioned above.

Although some synthetic aspects on the preparation of $(R)$ - or (S)- 1-(1-naphthyl)-ethyl urethanes containing a glycerol moiety are already known, ${ }^{27,28,35}$ the enantiospecific synthesis of $s n-1,2-$, sn-2,3-, and 1,3diacylglycerols as (S)-1-(1-naphthyl)-ethyl urethane derivatives starting from chiral reagent is currently incomplete. 
In this work we investigated a facile enantiospecific synthesis of (S)-1-(1-naphthyl)-ethyl urethane derivatives of $s n-1,2-$, sn-2,3- and $s n-1,3-D A G s$ starting from properly protected glycerol (1a-c), in order to obtain enantiopure reference samples (Scheme 1 and 2).

Then, the final compounds $\mathbf{4 a}, \mathbf{4 b}$ and $\mathbf{4 c}$ were characterized by ${ }^{1} \mathrm{H}$ - and ${ }^{13} \mathrm{C}-\mathrm{NMR}$ experiments and the results were compared with the data previously reported for the naphthylurethane derivatives of $s n-1,2-, s n-$ 2,3-, and sn-1,3-DAGs from olive oil. ${ }^{34}$ This comparison allowed us to confirm the structures and the configuration of the latter.

\section{Results and Discussion}

To perform the synthesis of (S)-1-(1-naphthyl)-ethyl urethane derivatives of $s n-1,2-$, sn-2,3- and 1,3-DAGs is of key importance to choose a suitable glycerol protective group which must be compatible with the derivatizing reagent. The latter must be stable to the hydrolytic reaction conditions of protective groups and not give migration phenomena.

For this purpose, commercially available (S)-(+)-2,2-dimethyl-1,3-dioxolan-4-methanol (1a) (Scheme 1), (R)-(-)-2,2-dimethyl-1,3-dioxolan-4-methanol (1b) (Scheme 1) and 2-phenyl-1,3-dioxan-5-ol (1c) (Scheme 2) were used as starting reagents.

Compounds $\mathbf{1 a}$ or $\mathbf{1 b}$ were initially reacted with (S)-(+)-(1-naphthyl)-ethyl isocyanate in toluene at $50{ }^{\circ} \mathrm{C}$ in the presence of catalytic amount of 4-pyrrolidinopyridine. ${ }^{25}$ After $12 \mathrm{~h}$ the reaction mixture was concentrated under vacuum. Purification of the crude by column chromatography on silica gel afforded derivatives $\mathbf{2 a}$ or $\mathbf{2 b}$ with high yield of 97 and 95\%, respectively.

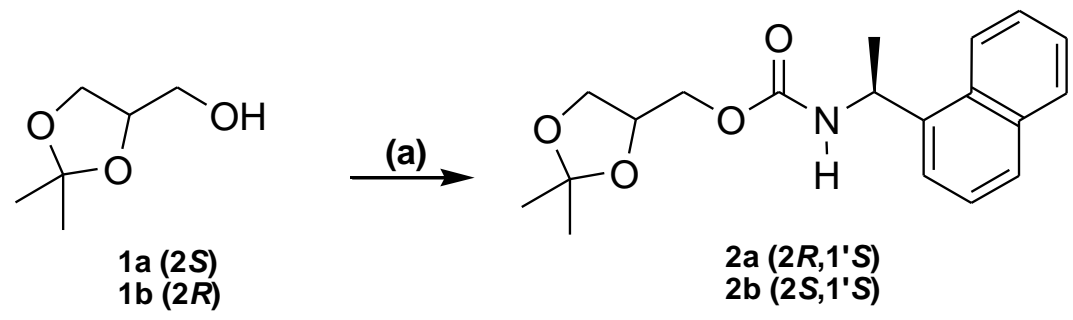

(b)

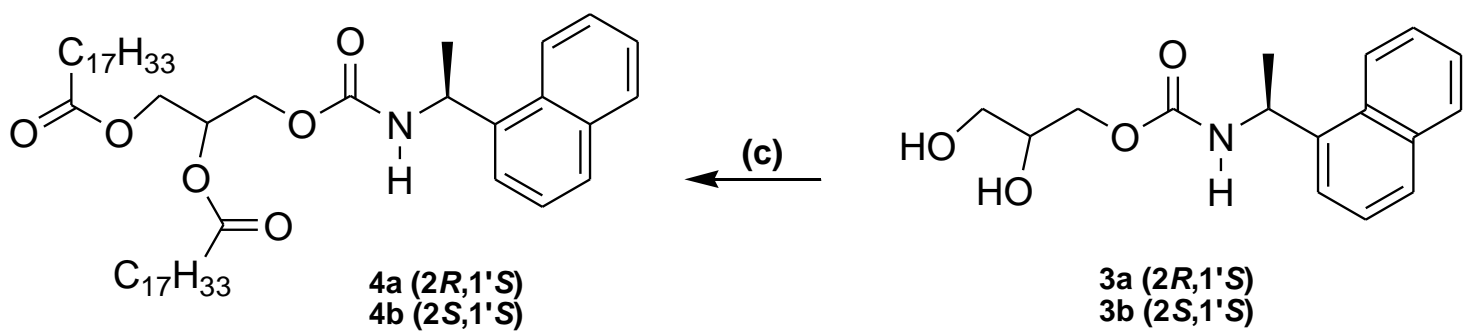

Scheme 1. (a) 4-Pyrrolidinopyridine, $(S)-(+)$ - or (R)-(-)- (1-naphthyl)ethyl isocyanate, toluene, $50{ }^{\circ} \mathrm{C}, 12 \mathrm{~h}$; (b) $0.5 \mathrm{~N} \mathrm{CF}_{3} \mathrm{COOH}, 0{ }^{\circ} \mathrm{C}$ then r.t., $24 \mathrm{~h}$; (c) oleic acid, DCC, DMAP, $0{ }^{\circ} \mathrm{C}, \mathrm{CH}_{2} \mathrm{Cl}_{2}$.

Despite compounds $\mathbf{2 a}$ and $\mathbf{2} \mathbf{b}$ are diastereomers, minimal differences in the ${ }^{1} \mathrm{H}$ - and ${ }^{13} \mathrm{C}$ - NMR spectra carried out in deuterated chloroform $\left(\mathrm{CDCl}_{3}\right)$ between the two isomers were observed. 
The superimposed ${ }^{1} \mathrm{H}-\mathrm{NMR}$ spectra of $\mathbf{2 a}$ and $\mathbf{2 b}$ (Figure 1 ) show slight difference of the $\mathrm{NH}$ at 5.21 and $5.15 \mathrm{ppm}$, respectively. Notably, it is possible to observe differences also in the range of 4.0-4.4 ppm ascribed to the glycerol moiety multiplets, in which tighter signals for compound $\mathbf{2} \mathbf{b}$ were observed. To the best of our knowledge, only limited spectroscopical data were reported in the literature for these kind of compounds as described by Gavagnin et al. They observed slight differences only at level of the methyl groups of the acetonide moiety of $\mathbf{1} \mathbf{a}$ and $\mathbf{1} \mathbf{b}$ derivatized as $(R)$-1-(1-naphthyl)-ethyl urethanes in ${ }^{1} \mathrm{H}-\mathrm{NMR}$ experiment when carried out in deuterated methanol $\left(\mathrm{CD}_{3} \mathrm{OD}\right)\left(1.38,1.33 \mathrm{ppm}\right.$ and $1.41,1.35 \mathrm{ppm}$, respectively). ${ }^{27}$

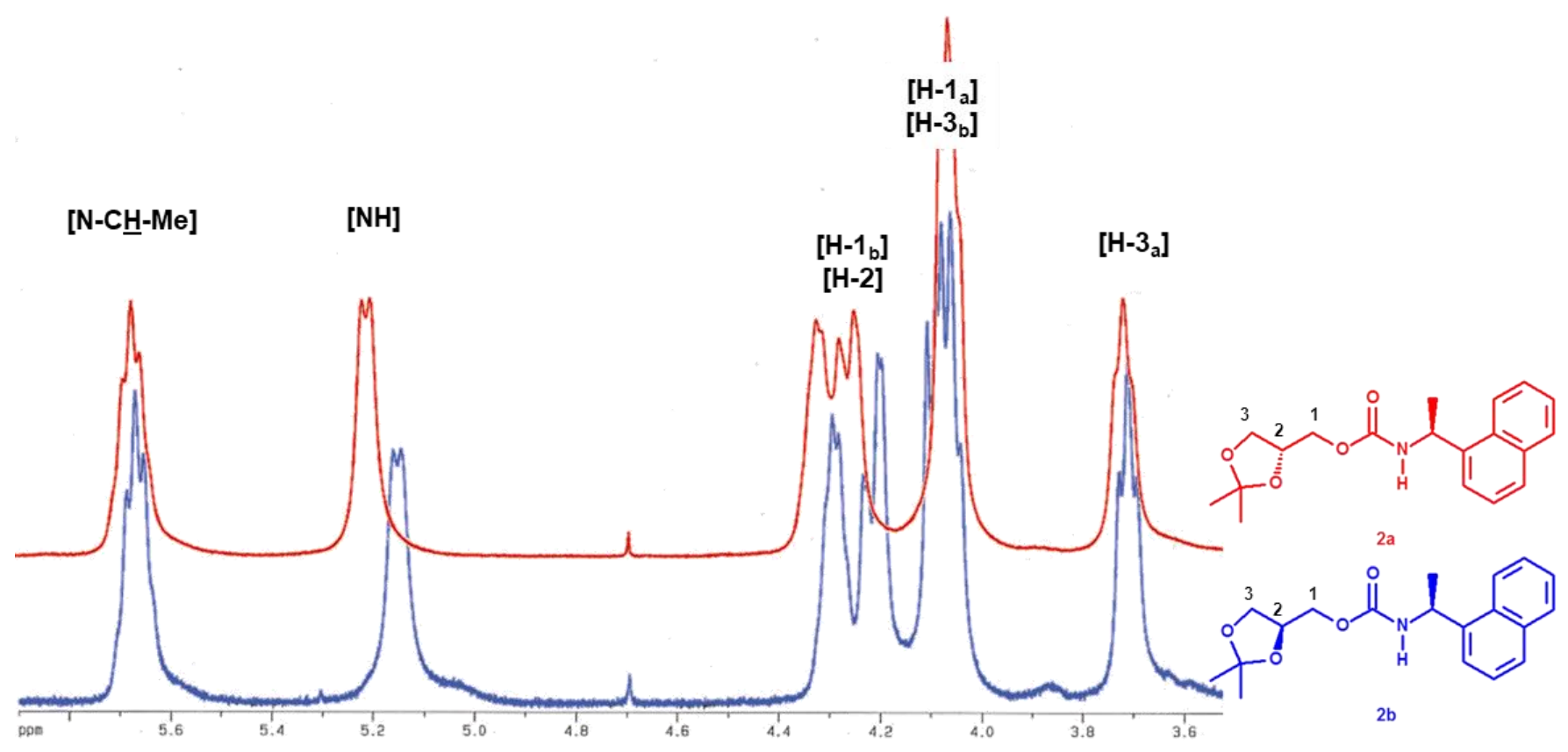

Figure 1. Differences of ${ }^{1} \mathrm{H}-\mathrm{NMR}$ spectra of compounds $\mathbf{2} \mathbf{a}$ and $\mathbf{2} \mathbf{b}$ in $\mathrm{CDCl}_{3}$.

In order to clarify that, we applied spectroscopic NMR techniques for a complete characterization of these derivatives. For this purpose, the homonuclear 2D ${ }^{1} \mathrm{H}$ (COSY) and heteronuclear $2 \mathrm{D}{ }^{1} \mathrm{H} /{ }^{13} \mathrm{C} \mathrm{HMQC}$ and $\mathrm{HMBC}$ experiments were particularly useful for the assignment of the chemical shift of the glycerol moiety hydrogens and carbons.

Heteronuclear multiple quantum correlation spectroscopy (HMQC) ${ }^{36,37}$ is an inverse chemical shift correlation experiment that, like heteronuclear $(\mathrm{X}, \mathrm{H})$ shift correlation spectroscopy (XHCORR), is used to determine which ${ }^{1} \mathrm{H}$ of a molecule is bonded to which ${ }^{13} \mathrm{C}$ nuclei (or other $\mathrm{X}$ nuclei). In this case, the HMQC spectra of $\mathbf{2} \mathbf{a}$ and $\mathbf{2} \mathbf{b}$ (Figure 2 ) allowed a better monitoring of the minimal differences existing between the two isomers resolving the problem related to the partial overlapping of hydrogens $\mathrm{H}-\mathrm{I}_{\mathrm{a}}$ and $\mathrm{H}-3_{\mathrm{b}}$ of the glycerol moiety (Figure 1). Furthermore, it was possible to establish a more accurate chemical shift of glycerol moiety protons when correlated with the corresponding carbons (Figure 2). As it is possible to observe in Figure 2, the major differences are related to the chemical shift of glycerol moiety hydrogens, rather than carbons.

Heteronuclear multiple bond correlation spectroscopy $(\mathrm{HMBC})^{36,38,39}$ is a modified version of $\mathrm{HMQC}$ suitable for determining long-range ${ }^{1} \mathrm{H}^{-13} \mathrm{C}$ connectivity. This experiment is useful in determining the structure and ${ }^{1} \mathrm{H}$ and ${ }^{13} \mathrm{C}$ assignments of molecules. In this case, the assignment of $\mathrm{C}-1$ of $2 \mathrm{a}$ was possible because there is a correlation between carbamic carbon at $155.1 \mathrm{ppm}$ and the protons at 4.03 and $4.25 \mathrm{ppm}$. These protons 
were previously correlated with the carbon at $65.2 \mathrm{ppm}$ by HMQC experiment (Figure 2). Thus, the results obtained by NMR experiments were particularly useful for the assignment of hydrogens and carbons of the glycerol moiety, as reported in Table 1.
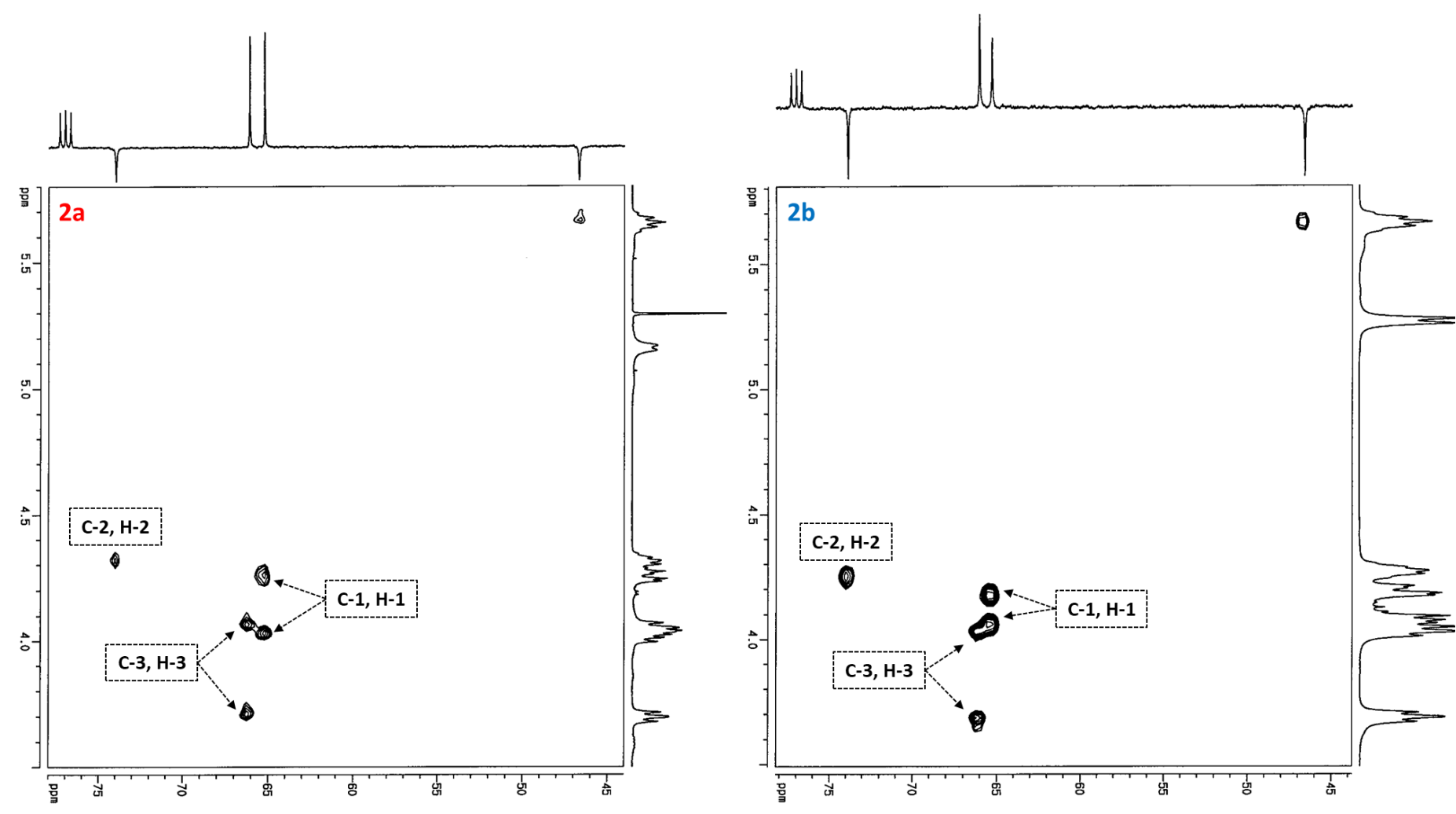

Figure 2. Heteronuclear $2 \mathrm{D}^{1} \mathrm{H} /{ }^{13} \mathrm{C}$ correlation (HMQC) detail of glycerol moiety of compounds $\mathbf{2 a}$ and $\mathbf{2 b}$.

Table 1. ${ }^{1} \mathrm{H}$ and ${ }^{13} \mathrm{C}$ chemical shift values of the glycerol moiety

\begin{tabular}{|c|c|c|c|c|c|c|}
\hline & \multicolumn{3}{|c|}{$2 a$} & \multicolumn{3}{|c|}{$2 b$} \\
\hline & $C-1$ & C-2 & C-3 & $C-1$ & $C-2$ & C-3 \\
\hline & $\mathrm{H}-1$ & $\mathrm{H}-2$ & $\mathrm{H}-3$ & H-1 & $\mathrm{H}-1$ & $\mathrm{H}-3$ \\
\hline${ }^{13} \mathrm{C}(\mathrm{ppm})$ & 65.2 & 74.0 & 66.1 & 65.3 & 73.9 & 66.0 \\
\hline \multirow{2}{*}{${ }^{1} \mathrm{H}(\mathrm{ppm})$} & 4.03 & \multirow{2}{*}{4.32} & 3.71 & 4.07 & \multirow{2}{*}{4.25} & 3.67 \\
\hline & 4.25 & & 4.07 & 4.18 & & 4.04 \\
\hline
\end{tabular}

The subsequent removal of the acetonide protective group of $\mathbf{2} \mathbf{a}$ and $\mathbf{2} \mathbf{b}$ was an important key step. We found that a mild hydrolysis performed with a $0.5 \mathrm{~N}$ trifluoroacetic acid solution in $\mathrm{THF} / \mathrm{H}_{2} \mathrm{O}(4: 1, \mathrm{v} / \mathrm{v})$ at room temperature did not affect naphthyl-ethyl urethane moiety, leading to the intermediates $\mathbf{3 a}$ or $\mathbf{3 b}$ with high yields (78 and $82 \%$, respectively). Under these reaction conditions, migration phenomena of the naphthylethyl urethane moiety were not observed.

Also the diastereoisomers $\mathbf{3 a}$ and $\mathbf{3 b}$ present minimal NMR spectroscopical differences. Indeed, the ${ }^{1} \mathrm{H}$ NMR spectra in DMSO- $d_{6}$ of $\mathbf{3 a}$ and $\mathbf{3 b}$ show little differences in the range of 3.7-4.1 ppm attributed to the methylene (C-1) bearing the carbamic ester of the glycerol moiety. These signals appear as two doublets of doublets with a chemical shift at 3.82 and 3.99 ppm for 3a and, 3.87 and 3.95 for $\mathbf{3 b}$ (Figure 3). 


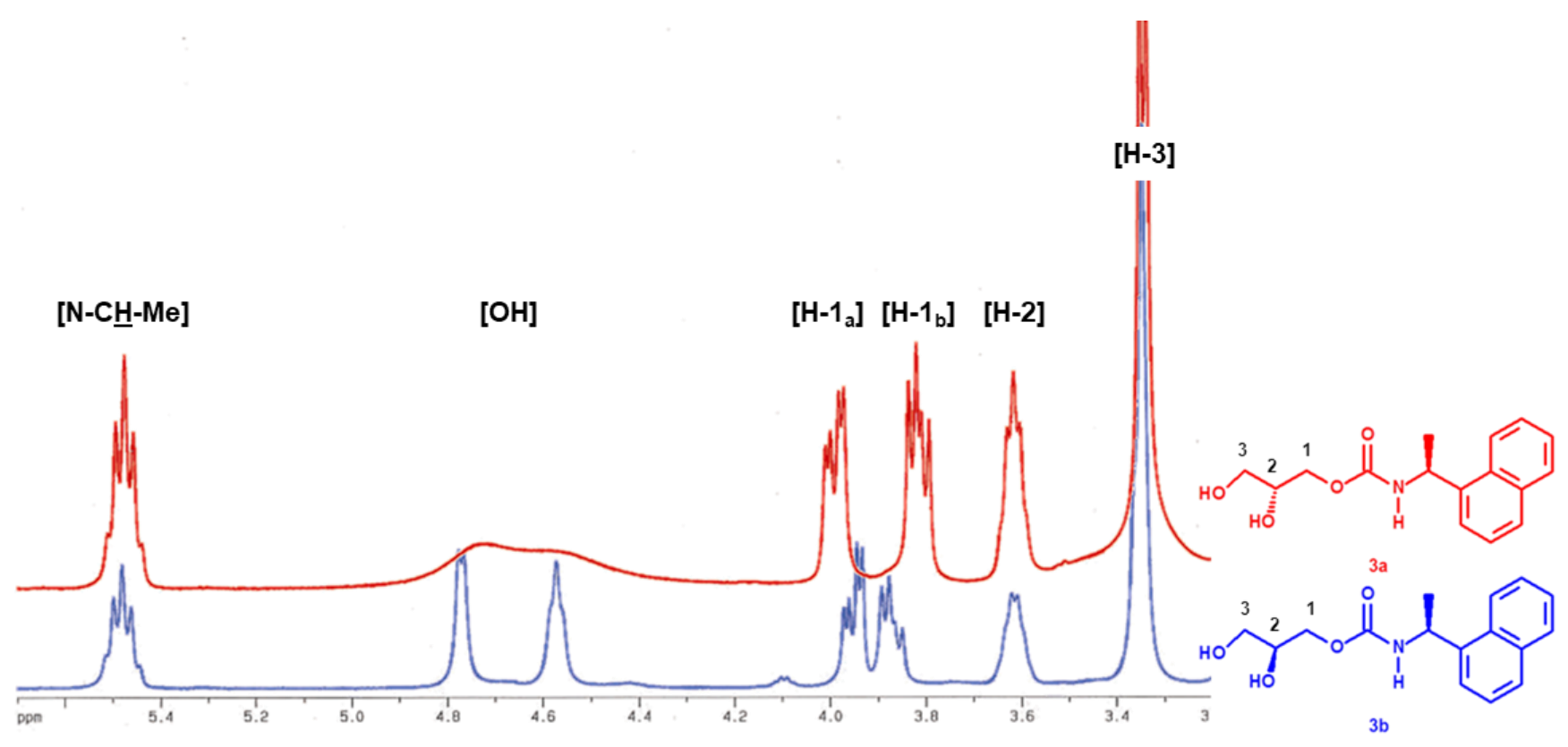

Figure 3. Differences of ${ }^{1} \mathrm{H}-\mathrm{NMR}$ spectra of compounds $\mathbf{3 a}$ and $\mathbf{3 b}$ in DMSO- $d_{6}$.

Homonuclear 2D ${ }^{1} \mathrm{H}$ (COSY) and heteronuclear 2D ${ }^{1} \mathrm{H} /{ }^{13} \mathrm{C}$ (HMQC) experiments allowed us a better monitoring of the minimal differences existing between the two isomers and to confirm the chemical shift assignment of hydrogens and carbons. As it is possible to observe in the HMQC spectra of $\mathbf{3 a}$ and $\mathbf{3 b}$ (Figure 4), the major differences are related, again, to the chemical shift of glycerol moiety hydrogens, rather than carbons (Table 2).
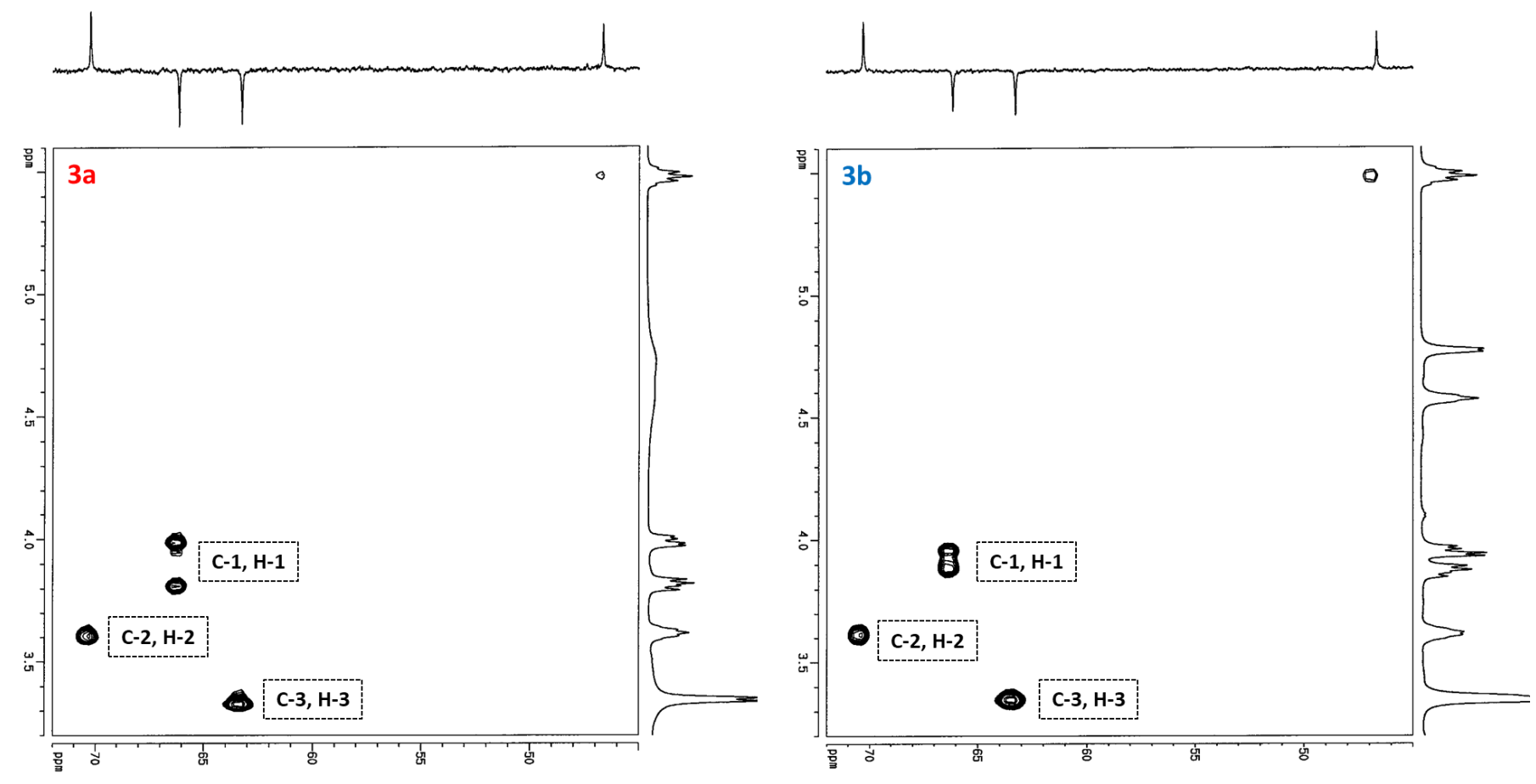

Figure 4. Heteronuclear $2 \mathrm{D}{ }^{1} \mathrm{H} /{ }^{13} \mathrm{C}$ correlation (HMQC) detail of glycerol moiety of compounds $\mathbf{3 a}$ and $\mathbf{3 b}$. 
Table 2. ${ }^{1} \mathrm{H}$ and ${ }^{13} \mathrm{C}$ chemical shift value of the glycerol moiety

\begin{tabular}{lllllll}
\hline & \multicolumn{9}{c}{ 3a } & & \multicolumn{2}{c}{ 3b } \\
\hline & C-1 & C-2 & C-3 & C-1 & C-2 & C-3 \\
& H-1 & H-2 & H-3 & H-1 & H-2 & H-3 \\
\hline${ }^{13} \mathrm{C}(\mathrm{ppm})$ & 66.1 & 70.2 & 63.3 & 66.1 & 70.3 & 63.3 \\
& 3.82 & & & 3.87 & & \\
${ }^{1} \mathrm{H}(\mathrm{ppm})$ & 3.99 & 3.62 & 3.35 & 3.95 & 3.62 & 3.34 \\
\hline
\end{tabular}

Finally, the esterification process to obtain DAG derivatives $\mathbf{4 a}$ or $\mathbf{4 b}$ was performed by reaction of the intermediates $\mathbf{3 a}$ and $\mathbf{3} \mathbf{b}$ with oleic acid in the presence of $N, N^{\prime}$-dicyclohexylcarbodiimide (DCC) and dimethylaminopyridine (DMAP), in dichloromethane at room temperature under nitrogen atmosphere. After purification by column chromatography on silica gel final compounds $\mathbf{4 a}$ or $\mathbf{4 b}$ were isolated with very good yields of 91 and $90 \%$, respectively.

DAG derivatives $\mathbf{4 a}$ and $\mathbf{4 b}$ have been investigated by means of ${ }^{1} \mathrm{H}-\mathrm{NMR}$ and ${ }^{13} \mathrm{C}-\mathrm{NMR}$, resulting identical to the samples obtained by HPLC separation of natural DAGs derivatized with (S)-1-(1-naphthyl)-ethyl urethanes as we previously mentioned. ${ }^{34}$

The synthetic approach to prepare $s n-1,2-$ and $s n-2,3-D A G$ derivatives $\mathbf{4 a}$ and $\mathbf{4 b}$ was also applied to the synthesis of 1,3-DAG derivative $4 c$ (Scheme 2 ).

Thus, the treatment of 1,3-benzylidene-glycerol 1c with $(S)-(+)-(1$-naphthyl)-ethyl isocyanate led to the (S)1-(1-naphthyl)-ethyl urethane derivative $\mathbf{2 c}$ with a yield of $93 \%$. The successive hydrolysis of intermediate $\mathbf{2 c}$ with a $0.5 \mathrm{~N}$ of trifluoroacetic acid solution in $\mathrm{THF} / \mathrm{H}_{2} \mathrm{O}(4: 1)$ at room temperature led to the compound $3 \mathrm{c}$ with a yield of $97 \%$. Finally, the treatment of $3 \mathrm{c}$ with oleic acid in the presence of DCC and DMAP, in dichloromethane led to the 1,3-DAG derivative $4 \mathrm{c}$ with a yield of $92 \%$.<smiles>OC1COC(c2ccccc2)OC1</smiles>

(a)<smiles>C[13CH][13CH]</smiles><smiles>C[C@H](NC(=O)OC1COC(c2ccccc2)OC1)c1cccc2ccccc12</smiles><smiles>c1ccccc1</smiles><smiles>C[C@H](NC(=O)OC(COC([14CH3])=O)COC([14CH3])=O)c1cccc2ccccc12</smiles><smiles>C[C@H](NC(=O)OC(CO)CO)c1cccc2ccccc12</smiles>

$3 c$

Scheme 2. (a) 4-Pyrrolidinopyridine, (S)-(+)-(1-naphthyl)ethyl isocyanate, Toluene, $50{ }^{\circ} \mathrm{C}, 12 \mathrm{~h}$;

(b) $0.5 \mathrm{~N} \mathrm{CF}_{3} \mathrm{COOH}, 0{ }^{\circ} \mathrm{C}$ then r.t., $20 \mathrm{~h}$; (c) oleic acid, DCC, DMAP, $0{ }^{\circ} \mathrm{C}, \mathrm{CH}_{2} \mathrm{Cl}_{2}$.

In Table 3 are summarized the ${ }^{1} \mathrm{H}$ and ${ }^{13} \mathrm{C}$ chemical shift values of glycerol moiety of $\mathbf{4 a}, \mathbf{4 b}$ and $\mathbf{4 c}$. 
Table 3. ${ }^{1} \mathrm{H}$ and ${ }^{13} \mathrm{C}$ chemical shift values of the glycerol moiety of $\mathbf{4 a}, \mathbf{4 b}$ and $\mathbf{4 c}$

\begin{tabular}{lccccccccc}
\hline & & 4a & & & 4b & & & 4c & \\
\hline & C-1 & C-2 & C-3 & C-1 & C-2 & C-3 & C-1 & C-2 & C-3 \\
& H-1 & H-2 & H-3 & H-1 & H-2 & H-3 & H-1 & H-2 & H-3 \\
\hline${ }^{13} \mathrm{C} \mathrm{(ppm)}$ & 62.9 & 69.2 & 62.1 & 62.8 & 69.1 & 62.1 & 62.4 & 69.8 & 62.4 \\
& 4.20 & & 4.15 & 4.23 & & 4.15 & & & \\
${ }^{1} \mathrm{H}(\mathrm{ppm})$ & 4.31 & 5.08 & 4.31 & 4.29 & 5.26 & 4.29 & $4.12-4.35$ & 5.22 & $4.12-4.35$ \\
\hline
\end{tabular}

In Figure 5, the superimposition of the ${ }^{1} \mathrm{H}-\mathrm{NMR}$ spectra, in the range of $4.0-4.5 \mathrm{ppm}$, evidencing the differences at level of glycerol moieties of compounds $4 a-c$, is reported for both synthetic and semi synthetic

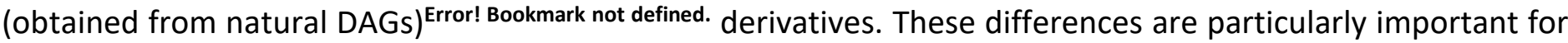
the characterization of the three DAG-(S)-1-(1-naphthyl)-ethyl urethane derivatives, as previously demonstrated. ${ }^{33}$ As shown in Figure 5, the pattern of the glycerol moiety signals of semisynthetic (obtained from sn-1,2-, sn-2,3-, and 1,3-DAGs from olive oil) and synthetic DAGs derivatized as (S)-1-(1-naphthyl)-ethyl urethane are identical.
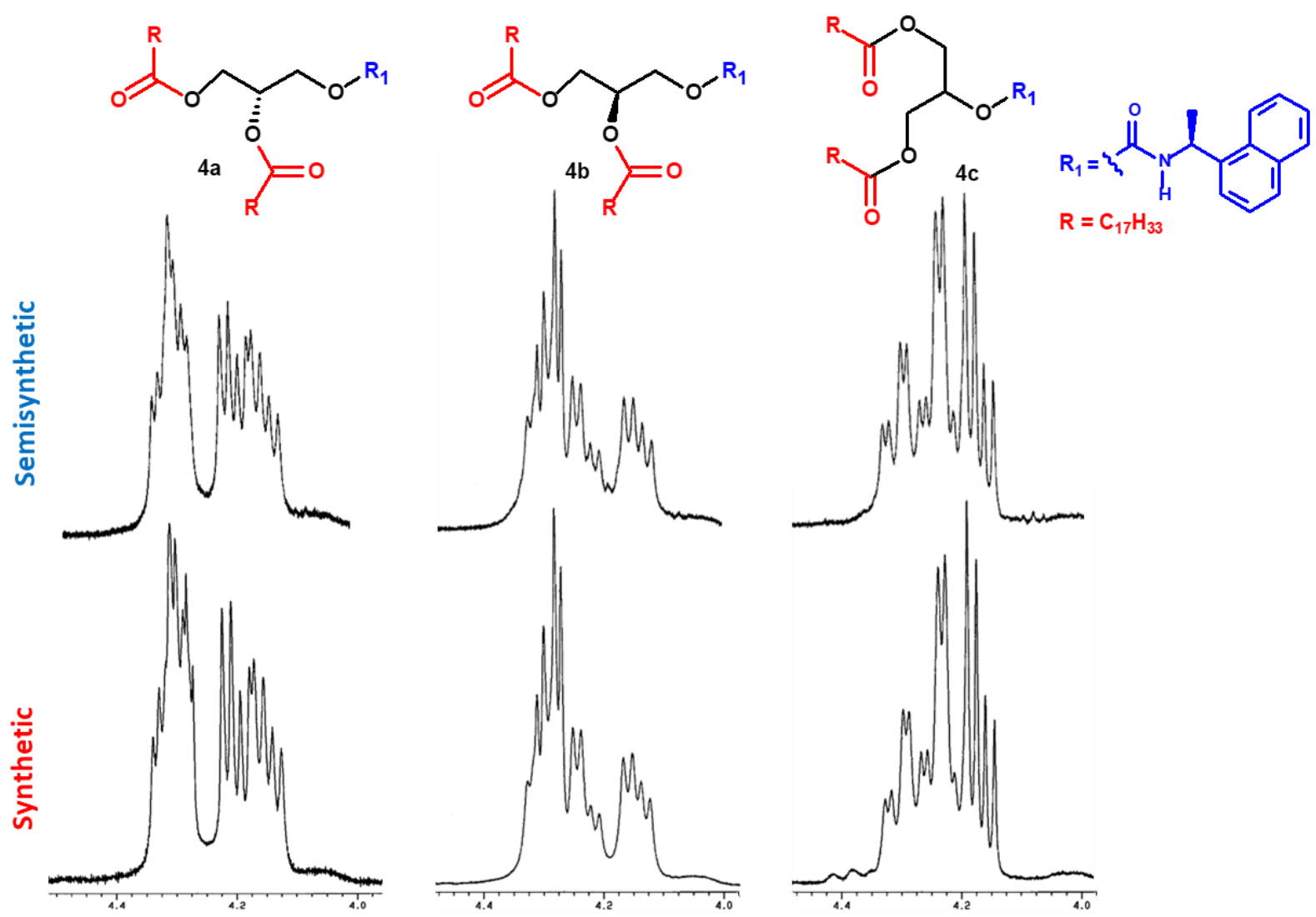

Figure 5. Comparison of the ${ }^{1} \mathrm{H}-\mathrm{NMR}$, in $\mathrm{CDCl}_{3}$, glycerol moiety of DAGs derivatives (semisynthetic and synthetic) in the range 4.0-4.4 ppm. 


\section{Conclusions}

In this paper a very high-yielding and manageable enantiospecific synthesis of stable sample of DAG derivatives $\mathbf{4 a}, \mathbf{4} \mathbf{b}$ and $\mathbf{4} \mathbf{c}$ has been performed in order to confirm the structure proposed for the DAG (S)-1-(1naphthyl)-ethyl urethane derivatives previously obtained from $s n-1,2-, s n-2,3-$, and $s n-1,3-D A G s$ from olive oil and separated by normal phase-high performance liquid chromatography. Full characterization of final compounds and intermediates was performed by NMR experiments. The comparison of ${ }^{1} \mathrm{H}$ and ${ }^{13} \mathrm{C}-\mathrm{NMR}$ spectra of DAG (S)-1-(1-naphthyl)-ethyl urethanes obtained from the enantiospecific synthetic pathway and from natural deriving isolated DAGs, allowed us to confirm the structures and the configuration previously proposed.

\section{Experimental Section}

General. All chemicals were purchased from the major chemical suppliers as highest purity grade and used without any further purification. Solvents were dried over standard drying agent and freshly distilled prior to use. Column chromatography was performed with Merck silica gel 60 (70-230 mesh ASTM) and monitored by thin layer chromatography (TLC) on silica gel 60 F254 with detection by charring with $8 \%$ phosphomolibdic acid in EtOH. ${ }^{1} \mathrm{H}$ and ${ }^{13} \mathrm{C}$ NMR spectra were recorded in $\mathrm{CDCl}_{3}$ or DMSO- $d_{6}$ with a Bruker Avance DPX 400 spectrometer at a frequency of 400 and $100 \mathrm{MHz}$, respectively. Chemical shifts $(\delta)$ are reported in ppm relative to TMS; J values are given in Hz. GC-MS analysis were obtained with HP-6890 gas chromatograph equipped with an HP-5973 mass-selective detector at an ionizing voltage of $70 \mathrm{eV}$, using a (5\% phenyl) methylpolysiloxane column, $12 \mathrm{~m}$ (Agilent DB-5ms). Optical rotations $\left([\alpha]_{\mathrm{D}}\right)$ were measured with automatic polarimeter Atago AP-100.

General procedure for the synthesis of [(1S)-1-naphthalen-1-ylethyl]carbamate derivatives $2 a, 2 b$ and $2 c$. To a solution of [(4S)-2,2-dimethyl-1,3-dioxolan-4-yl]methanol 1a ([(4R)-2,2-dimethyl-1,3-dioxolan-4-yl]methanol 2a or 2-phenyl-1,3-dioxan-5-ol 1c) (1 mmol) and 4-pyrrolidinopyridine as catalyst $(0.4 \mathrm{mmol})$ in dry toluene (10 $\mathrm{mL})$ under nitrogen and at room temperature, $(S)-(+)-(1-$ naphthyl)ethyl isocyanate $(1.2 \mathrm{mmol})$ was added. The reaction was warmed at $50{ }^{\circ} \mathrm{C}$ and monitored by $\mathrm{TLC}\left(\mathrm{CH}_{2} \mathrm{Cl}_{2} /\right.$ acetone, 19:1). After $12 \mathrm{~h}$ the reaction was concentrated under vacuum. The crude was purified by column chromatography on silica gel eluting with a mixture of $\mathrm{CH}_{2} \mathrm{Cl}_{2}$ /acetone $(99: 1, \mathrm{v} / \mathrm{v})$.

General procedure for the synthesis of dihydroxypropyl [(1S)-1-naphthalen-1-ylethyl]carbamate derivatives $\mathbf{3 a}, \mathbf{3 b}$ and $\mathbf{3 c}$. The naphthyl urethane derivative $\mathbf{2 a}(\mathbf{2} \mathbf{b}$ or $\mathbf{2 c})(1 \mathrm{mmol})$ was treated with a $0.5 \mathrm{~N} \mathrm{THF} / \mathrm{H}_{2} \mathrm{O}(4: 1)$ solution of trifluoroacetic acid $(5 \mathrm{~mL})$ at $0{ }^{\circ} \mathrm{C}$. After 30 minutes, the reaction was warmed at room temperature and stirred for $20 \mathrm{~h}$. The reaction mixture was treated with a $5 \%$ solution of $\mathrm{NaHCO}_{3}$ to reach pH 8 , then was extracted with EtOAc $(3 \mathrm{~mL} \times 3)$. The organic layer was dried on $\mathrm{Na}_{2} \mathrm{SO}_{4}$ and then concentrated under vacuum. The crude was purified by column chromatography on silica gel eluting with a mixture of $\mathrm{CH}_{2} \mathrm{Cl}_{2} / \mathrm{MeOH}$ (97:3, $\mathrm{v} / \mathrm{v})$.

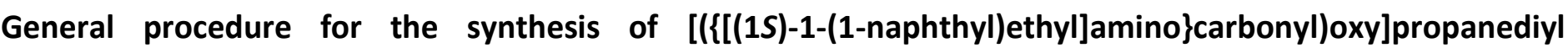
dioletate bis-oleate derivatives $(\mathbf{4 a}, \mathbf{4 b}$ and $\mathbf{4 c})$. To a stirred solution of the glyceryl naphthyl urethane derivative 3a (3b or 3c) $(1 \mathrm{mmol})$ and oleic acid $(2.1 \mathrm{mmol})$ in $\mathrm{CH}_{2} \mathrm{Cl}_{2}(13 \mathrm{~mL})$, at $0{ }^{\circ} \mathrm{C}$ and under nitrogen, a solution of DCC $(7 \mathrm{mmol})$ and DMAP $(0.2 \mathrm{mmol})$ in $\mathrm{CH}_{2} \mathrm{Cl}_{2}(10 \mathrm{~mL})$ was added dropwise. The reaction was monitored by $\mathrm{TLC}\left(\mathrm{CH}_{2} \mathrm{Cl}_{2} / \mathrm{MeOH}\right.$ 9:1). After $3 \mathrm{~h}$ at room temperature the reaction mixture was concentrated 
under vacuum. The crude was treated with $\mathrm{CH}_{2} \mathrm{Cl}_{2}(10 \mathrm{~mL})$ and filtered on Buchner to remove solid residue. The $\mathrm{CH}_{2} \mathrm{Cl}_{2}$ solution was concentrated under vacuum and purified by column chromatography on silica gel eluting with a mixture of $\mathrm{CH}_{2} \mathrm{Cl}_{2} /$ hexane $(1: 1, \mathrm{v} / \mathrm{v})$.

In order to avoid possible misunderstanding about the numbering of the glycerol moiety, in this paper we applied IUPAC rules numbering. Thus, the C-1 position of glycerol moiety of sn-1,2- and sn-2,3- DAGs always refer to the carbon bearing the naphthyl urethane group.

[(4R)-2,2-dimethyl-1,3-dioxolan-4-yl]methyl [(1S)-1-naphthalen-1-ylethyl]carbamate (2a). Yield $97 \%$ (319 $\mathrm{mg}$ ). Colorless oil. [ $\alpha]_{\mathrm{D}}{ }^{25}=-12.5^{\circ}$ (c 8.0, $\mathrm{CHCl}_{3}$ ). ${ }^{1} \mathrm{H}-\mathrm{NMR}\left(400 \mathrm{MHz}, \mathrm{CDCl}_{3}, \mathrm{ppm}\right): \delta_{\mathrm{H}} 1.36\left(\mathrm{~s}, 3 \mathrm{H}, \mathrm{CH}_{3}\right), 1.42(\mathrm{~s}$, $\left.3 \mathrm{H}, \mathrm{CH}_{3}\right), 1.65\left(\mathrm{~d}, J \mathrm{HHz}, 3 \mathrm{H}, \mathrm{CH}_{3}\right), 3.71\left(\mathrm{~m}, 1 \mathrm{H}, \mathrm{H}-3_{\mathrm{a}}\right.$ glycerol), 3.97-4.15 (m, 2H, H-3b $+\mathrm{H}-1_{\mathrm{a}}$ glycerol), 4.18-4.39

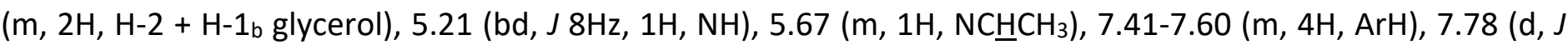
$8 \mathrm{~Hz}, 1 \mathrm{H}, \mathrm{ArH}), 7.87(\mathrm{~d}, J 8 \mathrm{~Hz}, 1 \mathrm{H}, \mathrm{ArH}) 8.12(\mathrm{~d}, J 8 \mathrm{~Hz}, \mathrm{ArH}) .{ }^{13} \mathrm{C}-\mathrm{NMR}\left(100 \mathrm{MHz}, \mathrm{CDCl}_{3}, \mathrm{ppm}\right): \delta_{\mathrm{C}} 21.6,25.3$, 26.6, 46.7, 65.2, 66.1, 74.0, 109.7, 122.2, 123.1, 125.2, 125.7, 126.4, 128.2, 128.8, 130.7, 133.9, 138.6, 155.1. GC-MS: $m / z=329[\mathrm{M}+], 256,214,170,155,129,101,57$.

(2R)-2,3-dihydroxypropyl [(1S)-1-naphthalen-1-ylethyl]carbamate (3a). Yield 78\% (226 mg). Colorless sticky oil. $[\alpha]_{\mathrm{D}}{ }^{25}=-5.3^{\circ}$ (c 2.7, EtOH). ${ }^{1} \mathrm{H}-\mathrm{NMR}\left(400 \mathrm{MHz}, \mathrm{DMSO}-d_{6}, \mathrm{ppm}\right): \delta_{\mathrm{H}} 1.45\left(\mathrm{~d}, J \mathrm{HHz}, 3 \mathrm{H}, \mathrm{CH}_{3}\right), 3.35(\mathrm{bd}, J=5 \mathrm{~Hz}$, 2H, H-3 glycerol), 3.62 (m, 1H, H-2 glycerol), 3.82 (dd, J 10, $6 \mathrm{~Hz}, 1 \mathrm{H}, \mathrm{H}-1_{\mathrm{a}}$ glycerol), 3.99 (dd, J 10, $4 \mathrm{~Hz}, 1 \mathrm{H}, \mathrm{H}-$ 1b glycerol), 4.55 (bs, $1 \mathrm{H}, \mathrm{OH}), 4.72$ (bs, $1 \mathrm{H}, \mathrm{OH}), 5.48\left(\mathrm{~m}, 1 \mathrm{H}, \mathrm{NC}_{\mathrm{HCH}}\right)_{3}, 7.46-7.61(\mathrm{~m}, 4 \mathrm{H}, \operatorname{ArH}), 7.80(\mathrm{~d}, J 8 \mathrm{~Hz}$, $1 \mathrm{H}, \mathrm{ArH}), 7.89(\mathrm{~d}, J 8 \mathrm{~Hz}, 1 \mathrm{H}, \mathrm{NH}), 7.94(\mathrm{~d}, J 8 \mathrm{~Hz}, 1 \mathrm{H}, \mathrm{ArH}), 8.15$ (d, J 8Hz, 1H, ArH). ${ }^{13} \mathrm{C}-\mathrm{NMR}(100 \mathrm{MHz}$, DMSO$\left.d_{6}, \mathrm{ppm}\right): \delta_{\mathrm{C}} 22.6,46.6,63.3,66.1,70.2,122.7,123.4,125.9,126.0,126.5,127.5,129.1,130.6,133.8,141.3$, 156.1. GC-MS: $m / z=289[\mathrm{M}+], 197,182,155,127,91$.

(2R)-3-[(\{[(1S)-1-naphthalen-1-ylethyl]amino\}carbonyl)oxy]propane-1,2-diyl dioleate (sn-1,2-dioleyl-3-[1-(S)1-(1-Naphthyl)ethyl-urethan]-glycerol) (4a). ${ }^{34}$ Yield 91\% (746 mg). Pale yellow oil. $[\alpha]_{\mathrm{D}}{ }^{25}=-2.6^{\circ}$ (c 3.8, $\mathrm{CHCl}_{3}$ ). ${ }^{1} \mathrm{H}-\mathrm{NMR}\left(400 \mathrm{MHz}_{\mathrm{CDCl}}, \mathrm{ppm}\right): \delta_{\mathrm{H}} 0.89\left(\mathrm{t}, J 7 \mathrm{~Hz}, 6 \mathrm{H}, 2 \mathrm{xCH}_{3}\right), 1.30\left(\mathrm{~m}, 40 \mathrm{H}, 20 \mathrm{xCH}_{2}\right), 1.59$ (bs, 4H,

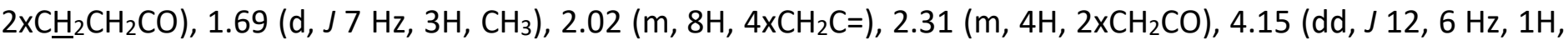
$\left.\mathrm{H}-3_{\mathrm{a}}\right), 4.20$ (dd, J 12, $\left.6 \mathrm{~Hz}, 1 \mathrm{H}, \mathrm{H}-1_{\mathrm{a}}\right), 4.31\left(\mathrm{~m}, 2 \mathrm{H}, \mathrm{H}-\mathrm{1}_{\mathrm{b}}+\mathrm{H}-3_{\mathrm{b}}\right), 5.08$ (d, J $\left.7.4 \mathrm{~Hz}, 1 \mathrm{H}, \mathrm{NH}\right), 5.28(\mathrm{~m}, 1 \mathrm{H}, \mathrm{H}-2), 5.37$ (m, 4H, olefinics), $5.68\left(\mathrm{~m}, 1 \mathrm{H}, \mathrm{NHCHCH}_{3}\right), 7.53(\mathrm{~m}, 4 \mathrm{H}, \mathrm{ArH}), 7.81(\mathrm{~d}, J 7.5 \mathrm{~Hz}, 1 \mathrm{H}, \mathrm{ArH}), 8.12(\mathrm{~d}, J 7.9 \mathrm{~Hz}, 1 \mathrm{H}$, $\operatorname{ArH}), 8.13(\mathrm{~d}, J 8 \mathrm{~Hz}, 1 \mathrm{H}, \mathrm{ArH}) .{ }^{13} \mathrm{C}-\mathrm{NMR}\left(100 \mathrm{MHz}, \mathrm{CDCl}_{3}, \mathrm{ppm}\right): \delta_{\mathrm{C}} 14.1,21.6,22.7,24.8,27.16,27.21,29.0$, $29.11,29.15,29.3,29.5,29.69,29.75,31.9,34.0,34.2,46.7,62.1,62.9,69.2,122.2,123.1,125.2,125.8,126.5$, $128.0,128.3,128.9,129.7,130.2,133.9,138.4,154.9,172.9,173.3$.

[(4S)-2,2-dimethyl-1,3-dioxolan-4-yl]methyl [(1S)-1-naphthalen-1-ylethyl]carbamate (2b). Yield $95 \%$ (313 mg). Colorless oil. $[\alpha]_{\mathrm{D}}{ }^{25}=-5.0^{\circ}$ (c 4.0, $\left.\mathrm{CHCl}_{3}\right) .{ }^{1} \mathrm{H}-\mathrm{NMR}\left(400 \mathrm{MHz}, \mathrm{CDCl}_{3}, \mathrm{ppm}\right): \delta_{\mathrm{H}} 1.35\left(\mathrm{~s}, 3 \mathrm{H}, \mathrm{CH}_{3}\right), 1.41(\mathrm{~s}$, $\left.3 \mathrm{H}, \mathrm{CH}_{3}\right), 1.65\left(\mathrm{~d}, J 6.5 \mathrm{~Hz}, 3 \mathrm{H}, \mathrm{CH}_{3}\right), 3.71$ (bt, J $7 \mathrm{~Hz}, 1 \mathrm{H}, \mathrm{H}-3_{\mathrm{a}}$ glycerol), 3.99-4.17 (m, 2H, H-3 $\mathrm{b}_{\mathrm{b}}+\mathrm{H}-\mathrm{1}_{\mathrm{a}}$ glycerol), 4.17-4.35 (m, 2H, H-1 b + H-2 glycerol), $5.15(\mathrm{bd}, J 6.5 \mathrm{~Hz}, 1 \mathrm{H}, \mathrm{NH}), 5.67\left(\mathrm{~m}, 1 \mathrm{H}, \mathrm{NCHCH}_{3}\right), 7.42-7.63(\mathrm{~m}, 4 \mathrm{H}$, $\operatorname{ArH}), 7.79(\mathrm{~d}, J 8 \mathrm{~Hz}, 2 \mathrm{H}, \mathrm{ArH}), 7.87(\mathrm{~d}, J 8 \mathrm{~Hz}, 1 \mathrm{H}, \mathrm{ArH}), 8.12(\mathrm{~d}, J 8 \mathrm{~Hz}, 1 \mathrm{H}, \mathrm{ArH}) .{ }^{13} \mathrm{C}-\mathrm{NMR}\left(100 \mathrm{MHz} \mathrm{CDCl}_{3}\right.$, ppm): $\delta_{c} 21.6,25.2,26.6,46.6,65.3,66.0,73.9,109.7,122.1,123.1,125.2,125.7,126.3,128.1,128.7,130.7$, 133.8, 138.5, 155.1. GC-MS: $m / z=329[\mathrm{M}+], 256,214,170,155,129,101,57$.

(2S)-2,3-dihydroxypropyl [(1S)-1-naphthalen-1-ylethyl]carbamate (3b). Yield: 82\% (238 mg). Colorless sticky oil. $[\alpha]_{D}{ }^{25}=-12.3^{\circ}$ (c 2.6, EtOH). ${ }^{1} \mathrm{H}-\mathrm{NMR}\left(400 \mathrm{MHz}, \mathrm{DMSO}-d_{6}, \mathrm{ppm}\right): \delta_{\mathrm{H}} 1.45$ (d, J 7Hz, 3H, CH $), 3.34$ (bs, $2 \mathrm{H}$, H-3 glycerol), 3.62 (m, 1H, H-2 glycerol), 3.87 (dd, J 11, $6 \mathrm{~Hz}, 1 \mathrm{H}, \mathrm{H}-1_{\mathrm{a}}$ glycerol), 3.95 (dd, J 11, $4 \mathrm{~Hz}, 1 \mathrm{H}, \mathrm{H}-1_{\mathrm{b}}$ glycerol), $4.57\left(\mathrm{~m}, 1 \mathrm{H}, \mathrm{CH}_{2} \mathrm{OH}\right), 4.77(\mathrm{bd}, J 4 \mathrm{~Hz}, 1 \mathrm{H}, \mathrm{CHOH}), 5.48\left(\mathrm{~m}, 1 \mathrm{H}, \mathrm{NCHCH}_{3}\right), 7.44-7.64(\mathrm{~m}, 4 \mathrm{H}, \mathrm{ArH}), 7.80$ $(\mathrm{d}, J 8 \mathrm{~Hz}, 1 \mathrm{H}, \mathrm{ArH}), 7.91(\mathrm{~d}, J 9 \mathrm{~Hz}, 1 \mathrm{H}, \mathrm{NH}), 7.94(\mathrm{~d}, J 8 \mathrm{~Hz}, 1 \mathrm{H}, \mathrm{ArH}), 8.15(\mathrm{~d}, J 8 \mathrm{~Hz}, 1 \mathrm{H}, \operatorname{ArH}) .{ }^{13} \mathrm{C}-\mathrm{NMR}(100$ $\left.\mathrm{MHz}, \mathrm{DMSO}-d_{6}, \mathrm{ppm}\right): \delta_{\mathrm{c}} 22.6,46.7,63.3,66.1,70.3,122.7,123.4,129.9,126.0,126.6,127.5,129.1,130.6$, 133.8, 141.3, 156.1. GC-MS: $m / z=289[\mathrm{M}+], 197,182,155,127,91$. 
(2S)-3-[(\{[(1S)-1-naphthalen-1-ylethyl]amino\}carbonyl)oxy]propane-1,2-diyl dioleate (sn-2,3-dioleyl-1-[(1-(S)1-(1-Naphthyl)ethyl-urethan]-glycerol) (4b). ${ }^{33}$ Yield 93\% (763 mg). Pale yellow oil. $[\alpha]_{D}{ }^{25}=-2.0^{\circ}$ (c 9.8, $\mathrm{CHCl}_{3}$ ). ${ }^{1} \mathrm{H}$ NMR $\left(400 \mathrm{MHz}, \mathrm{CDCl}_{3}, \mathrm{ppm}\right): \delta_{\mathrm{H}} 0.89\left(\mathrm{t}, 6 \mathrm{H}, J 7 \mathrm{~Hz}, 2 \times \mathrm{CH}_{3}\right), 1.29\left(\mathrm{~m}, 40 \mathrm{H}, 20 \times \mathrm{CH}_{2}\right), 1.60$ (bs, 4H, 2xCH $\mathrm{CH}_{2} \mathrm{CO}$ ), 1.69 (d, J $\left.7 \mathrm{~Hz}, 3 \mathrm{H}, \mathrm{CH}_{3}\right), 2.03\left(\mathrm{~m}, 8 \mathrm{H}, 4 x \mathrm{CH}_{2} \mathrm{C}=\right), 2.31\left(\mathrm{~m}, 4 \mathrm{H}, 2 \mathrm{xCH}_{2} \mathrm{CO}\right), 4.15(\mathrm{dd}, J 12,6 \mathrm{~Hz}, 1 \mathrm{H}$, $\left.\mathrm{H}-3_{\mathrm{a}}\right), 4.23$ (dd, J 11, $\left.6 \mathrm{~Hz}, 1 \mathrm{H}, \mathrm{H}-1_{\mathrm{a}}\right), 4.29\left(\mathrm{~m}, 2 \mathrm{H}, \mathrm{H}-1_{\mathrm{b}}+\mathrm{H}-3_{\mathrm{b}}\right), 5.09$ (d, J $\left.7.5 \mathrm{~Hz}, 1 \mathrm{H}, \mathrm{NH}\right), 5.26(\mathrm{~m}, 1 \mathrm{H}, \mathrm{H}-2), 5.37$ (m, 4H, olefinics), $5.67\left(\mathrm{~m}, 1 \mathrm{H}, \mathrm{NHCHCH}_{3}\right), 7.53(\mathrm{~m}, 4 \mathrm{H}, \mathrm{ArH}), 7.82(\mathrm{~d}, J 7.9 \mathrm{~Hz}, 1 \mathrm{H}, \mathrm{ArH}), 7.90(\mathrm{~d}, J 7.5 \mathrm{~Hz}, 1 \mathrm{H}$, $\mathrm{ArH}), 8.11(\mathrm{~d}, J 7.9 \mathrm{~Hz}, 1 \mathrm{H}, \mathrm{ArH}) .{ }^{13} \mathrm{C} \mathrm{NMR}\left(100 \mathrm{MHz}, \mathrm{CDCl}_{3}, \mathrm{ppm}\right): \delta_{\mathrm{C}} 14.1,21.6,22.7,24.8,27.18,27.22,29.0$, 29.1, 29.2, 29.3, 29.5, 29.7, 29.8, 31.9, 34.0, 34.2, 46.7, 62.1, 62.8, 69.1, 122.3, 123.1, 125.3, 125.8, 126.5, $128.0,128.3,128.9,129.7,130.0,130.8,133.9,138.4,154.9,172.9,173.3$.

2-Phenyl-1,3-dioxan-5-yl [(1S)-1-naphthalen-1-ylethyl]carbamate (2c). Yield 93\% (351 mg). White solid, mp 183.1-184.2 ${ }^{\circ} \mathrm{C} .[\alpha]_{\mathrm{D}}{ }^{25}=+2.0^{\circ}\left(\mathrm{c} 5.0, \mathrm{CHCl}_{3}\right) .{ }^{1} \mathrm{H}-\mathrm{NMR}\left(400 \mathrm{MHz}, \mathrm{CDCl}_{3}, \mathrm{ppm}\right): \delta_{\mathrm{H}} 1.68\left(\mathrm{~d}, J \mathrm{~Hz}, 3 \mathrm{H}, \mathrm{CH}_{3}\right), 4.14-$ $4.35(\mathrm{~m}, 3 \mathrm{H}$, glycerol), 4.40 (d, J 13Hz, 1H, glycerol), 4.72 (bs, $1 \mathrm{H}$, glycerol), 5.42 (d, J 8Hz, $1 \mathrm{H}, \mathrm{NH}), 5.58(\mathrm{~s}, 1 \mathrm{H}$, O-CH-O), $5.70(\mathrm{~m}, 1 \mathrm{H}, \mathrm{CHNH}), 7.34-7.45(\mathrm{~m}, 3 \mathrm{H}, \mathrm{PhH}), 7.47-7.63(\mathrm{~m}, 6 \mathrm{H}, \mathrm{PhH}+\mathrm{ArH}), 7.81(\mathrm{~d}, J 8 \mathrm{~Hz}, 1 \mathrm{H}, \mathrm{ArH})$, $7.90(\mathrm{~d}, J 9 \mathrm{~Hz}, 1 \mathrm{H}, \mathrm{ArH}), 8.16$ (d, J 8Hz, $1 \mathrm{H}, \mathrm{ArH}) .{ }^{13} \mathrm{C}-\mathrm{NMR}\left(100 \mathrm{MHz}, \mathrm{CDCl}_{3}, \mathrm{ppm}\right): \delta_{\mathrm{C}}=22.0,46.8,66.2,69.5$, $101.1,122.2,123.1,125.3,125.7,125.9,126.4,128.1,128.2,128.9,129.0,130.7,133.9,137.8,138.5,155.0$. GC-MS: $\mathrm{m} / \mathrm{z}=377[\mathrm{M}+], 197,182,155,127,77$.

2-Hydroxy-1-(hydroxymethyl)ethyl [(1S)-1-naphthalen-1-ylethyl]carbamate (3c). Yield 97\% (280 mg). White solid, $\mathrm{mp}=106.5-107.8^{\circ} \mathrm{C}$. $[\alpha]_{\mathrm{D}}{ }^{25}=+1.1^{\circ}$ (c 3.9, EtOH). ${ }^{1} \mathrm{H}-\mathrm{NMR}\left(400 \mathrm{MHz}, \mathrm{CDCl}_{3}, \mathrm{ppm}\right): \delta_{\mathrm{H}} 1.67(\mathrm{~d}, \mathrm{~J} 7 \mathrm{~Hz}, 3 \mathrm{H}$, $\mathrm{CH} 3), 3.74-3.89\left(\mathrm{~m}, 3 \mathrm{H}, 2 \times \mathrm{CH}_{2} \mathrm{OH}\right), 4.82(\mathrm{~m}, 1 \mathrm{H}, \mathrm{CH}-\mathrm{OR}), 5.27(\mathrm{~d}, \mathrm{~J} 7 \mathrm{~Hz}, 1 \mathrm{H}, \mathrm{NH}), 5.66\left(\mathrm{~m}, 1 \mathrm{H}, \mathrm{CHCH}_{3}\right), 7.42-$ $7.63(\mathrm{~m}, 4 \mathrm{H}, \mathrm{ArH}), 7.80(\mathrm{~d}, J 8 \mathrm{~Hz}, 1 \mathrm{H}, \mathrm{ArH}), 7.88(\mathrm{~d}, J 8 \mathrm{~Hz}, 1 \mathrm{H}, \mathrm{ArH}), 8.11(\mathrm{~d}, J 8 \mathrm{~Hz}, 1 \mathrm{H}, \operatorname{ArH}) .{ }^{13} \mathrm{C}-\mathrm{NMR}(100$ $\left.\mathrm{MHz}, \mathrm{CDCl}_{3}, \mathrm{ppm}\right): \delta_{\mathrm{C}} 21.6,46.8,62.7,76.1,122.2,123.0,125.3,125.8,126.5,128.2,128.9,130.7,133.9$, 138.6, 155.8. GC-MS: $\mathrm{m} / \mathrm{z}=289[\mathrm{M}+], 197,182,155,127,91$.

2-[(\{[(1S)-1-naphthalen-1-ylethyl]amino\}carbonyl)oxy]propane-1,3-diyl bis-oleate (1,3-Dioleyl-2-[1-(S)-1-(1naphthyl)ethyl-urethan]glycerol) (4c). ${ }^{34}$ Yield: $90 \%$ (738 mg). Pale yellow oil. $[\alpha]_{\mathrm{D}}{ }^{25}=-2.6^{\circ}$ (c 4.7, $\left.\mathrm{CHCl}_{3}\right) .{ }^{1} \mathrm{H}-$ NMR $\left(400 \mathrm{MHz}, \mathrm{CDCl}_{3}, \mathrm{ppm}\right): \delta_{\mathrm{H}} 0.90\left(\mathrm{t}, J 7 \mathrm{~Hz}, 6 \mathrm{H}, 2 \mathrm{xCH}_{3}\right), 1.28\left(\mathrm{~m}, 40 \mathrm{H}, 20 \mathrm{xCH}_{2}\right), 1.59\left(\mathrm{~m}, 4 \mathrm{H}, 2 \mathrm{xC}_{2} \mathrm{CH}_{2} \mathrm{CO}\right)$, $1.69\left(\mathrm{~d}, J 6.7 \mathrm{~Hz}, 3 \mathrm{H}, \mathrm{CH}_{3}\right), 2.02\left(\mathrm{~m}, 8 \mathrm{H}, 4 \mathrm{xCH}_{2} \mathrm{C}=\right), 2.23\left(\mathrm{t}, J 7.3 \mathrm{~Hz}, 2 \mathrm{H}, \mathrm{CH}_{2} \mathrm{CO}\right), 2.36\left(\mathrm{t}, J 7.3 \mathrm{~Hz}, 2 \mathrm{H}, \mathrm{CH}_{2} \mathrm{CO}\right)$, 4.12-4.35 (m, $4 \mathrm{H}, \mathrm{H}-1$ and $\mathrm{H}-3), 5.10(\mathrm{~d}, J 8 \mathrm{~Hz}, 1 \mathrm{H}, \mathrm{NH}), 5.22(\mathrm{~m}, 1 \mathrm{H}, \mathrm{H}-2), 5.37(\mathrm{~m}, 4 \mathrm{H}$, olefinics), $5.68(\mathrm{~m}, 1 \mathrm{H}$, $\left.\mathrm{NHCHCH}_{3}\right), 7.53(\mathrm{~m}, 4 \mathrm{H}, \mathrm{ArH}), 7.82(\mathrm{~d}, J 8 \mathrm{~Hz}, 1 \mathrm{H}, \mathrm{ArH}), 7.90(\mathrm{~d}, J 8 \mathrm{~Hz}, 1 \mathrm{H}, \mathrm{ArH}), 8.14(\mathrm{~d}, J 8.3 \mathrm{~Hz}, 1 \mathrm{H}, \mathrm{ArH}) .{ }^{13} \mathrm{C}$ NMR $\left(100 \mathrm{MHz}, \mathrm{CDCl}_{3}, \mathrm{ppm}\right): \delta_{\mathrm{c}} 14.2,21.7,22.8,24.8,24.9,27.25,27.30,29.2,29.4,29.6,29.8,29.9,32.0$, $34.0,34.2$, 46.9, 62.4, 69.8, 122.3, 123.2, 125.2, 125.9, 128.4, 129.0, 129.4, 129.8, 130.1, 134.0, 138.5, 154.5, 173.3.

\section{Acknowledgements}

We gratefully acknowledge the Department of Pharmaceutical Sciences - Università degli Studi di Perugia within financing program "Fondo per il sostegno della Ricerca di Base 2018: Sviluppo di metodologie innovative per la sintesi efficiente di composti eterociclici, molecole drug-like e intermedi sintetici ad alto valore aggiunto". 


\section{References}

1. Fattore M.; Montesano D.; Pagano E.; Teta R.; Borrelli F.; Mangoni A.; Seccia S.; Albrizio S. J. Food Comp. Anal. 2016, 53, 61.

https://doi.org/10.1016/i.jfca.2016.08.008

2. Borrelli, F.; Borbone, N.; Capasso, R.; Montesano, D.; De Marino, S.; Aviello, G.; Aprea, G.; Masone, S.; Izzo, A. A. J. Ethnopharmacol. 2009, 122, 434.

https://doi.org/10.1016/j.jep.2009.02.003

3. Montesano, D.; Gennari, O.; Seccia, S.; Albrizio, S. Food Anal. Meth. 2012, 5, 710.

https://doi.org/10.1007/s12161-011-9305-2

4. Montesano, D.; Fallarino, F.; Cossignani, L.; Bosi, A.; Simonetti, M.S.; Puccetti, P.; Damiani, P. Eur. Food Res. Technol. 2008, 226, 327. https://doi.org/10.1007/s00217-006-0541-4

5. Santoro, S.; Superchi, S.; Messina, F.; Santoro, E.; Rosati, O.; Santi, C.; Marcotullio, M. C. J. Nat. Prod. 2013, 76, 1254.

https://doi.org/10.1021/np400114b

6. Marcotullio, M. C.; Rosati, O.; Maltese, F.; Messina, F. Rec. Nat. Prod. 2013, 7, 239.

7. Curini, M.; Maltese, F.; Marcotullio, M. C.; Menghini, L.; Pagiotti, R.; Rosati, O.; Altinier, G.; Tubaro, A. Planta Med. 2005, 71, 194.

https://doi.org/10.1055/s-2005-837792

8. Lee, Y.-Y.; Tang, T.-K.; Phuah, E.-T.; Tan, C.-P.; Wang, Y.; Li, Y.; Cheong, L.-Z.; Lai, O.-M. Crit. Rev. Food Sci. Nutr. 2019.

https://doi.org/10.1080/10408398.2019.1650001

9. Eichmann, T. O.; Lass, A. Cell. Mol. Life Sci. 2015, 72, 3931

10. Becker, K. P.; Hannun, Y. A. Diacylglycerols. In Bioactive Lipids, 1st ed.; Nicolaou, A., Kokotos, G., Eds.; The Oily Press: Bridgwater, U.K., 2004; pp. 37.

https://doi.org/10.1533/9780857097934.37

11. Carrasco, S.; Mérida, I. Trends Biochem. Sci. 2007, 32, 27.

https://doi.org/10.1016/j.tibs.2006.11.004

12. Gómez-Fernández, J. C.; Corbalán-García, S. Chem. Phys. Lipids 2007, 148, 1. https://doi.org/10.1016/j.chemphyslip.2007.04.003

13. Nyilas, Á. Chem. Phys. Lipids 1997, 87, 171.

https://doi.org/10.1192/bjp.171.1.87a

14. Sonnet, P. E.; Oliver, J. E.; Waters, R. M.; King, G.; Panicker, S. Chem. Phys. Lipids 1995, 78, 203.

https://doi.org/10.1016/0009-3084(95)02477-Z

15. Tanaka, R.; Sakano, Y.; Nagatsu, A.; Shibuya, M.; Ebizuka, Y.; Goda, Y. Bioorg. Med. Chem. Lett. 2005, 15, 159.

https://doi.org/10.1016/j.bmcl.2004.10.013

16. Mariani, C.; Fedeli, E. Riv. Ital. Sostanze Grasse 1985, 62, 3.

17. Leone, A. M.; Santoro, M.; Luzzi, V. A.; La Notte, E.; Gambacorta, G. Riv. Ital. Sostanze Grasse 1988, 65, 613.

18. Ferrario, A. Riv. Ital. Sostanze Grasse 1989, 66, 681.

19. Frega, N.; Bocci, F.; Lercker, G. Riv. Ital. Sostanze Grasse 1993, 70, 153. 
20. Cossignani, L.; Luneia, R.; Damiani, P.; Simonetti, M. S.; Riccieri, R.; Tiscornia, E. Eur. Food Res. Technol., 2007, 224, 379.

https://doi.org/10.1007/s00217-006-0327-8

21. Villeneuve, P.; Muderhawa, J. M.; Graille, J.; Haas, M. J. J. Mol. Catal. B: Enzym. 2000, 9, 113. https://doi.org/10.1016/S1381-1177(99)00107-1

22. Blasi, F.; Cossignani, L.; Simonetti, M. S.; Damiani, P. Enz. Microb. Technol. 2007, 41, 727. https://doi.org/10.1016/j.enzmictec.2007.06.005

23. Maki, K. C.; Davidson, M. H.; Tsushima, R.; Matsuo, N.; Tokimitsu, I.; Umporowicz, D. M.; Dicklin, M. R.; Foster, G. S.; Ingram, K. A.; Anderson, B. D.; Frost, S. D.; Bell, M. Am. J. Clin. Nutr. 2002, 76, 1230. https://doi.org/10.1093/ajcn/76.6.1230

24. Kawashima, H.; Takase, H.; Yasunaga, K.; Wakaki, Y.; Katsuragi, Y.; Mori, K.; Yamaguchi, T.; Hase, T.; Matsuo, N.; Yasukawa, T.; Tokimitsu, I.; Koyama, W. J. Am. Diet. Assoc. 2008, 108, 57. https://doi.org/10.1016/i.jada.2007.10.014

25. Michelsen, P.; Aronsson, G.; Odham, B.; Åkesson, B. J. Chromatogr. A 1985, 350, 417. https://doi.org/10.1016/S0021-9673(01)93547-2

26. Santinelli, F.; Damiani, P.; Christie, W. W. J. Am. Oil Chem. Soc. 1992, 69, 552. https://doi.org/10.1007/BF02636107

27. Gavagnin, M.; Spinella, A.; Cimino, G.; Sodano, G. Tetrahedron Lett. 1990, 31, 6093. https://doi.org/10.1016/S0040-4039(00)98037-7

28. Cimino, G.; Crispino, A.; Gavagnin, M.; Trivellone, E.; Zubia, E.; Martínez, E.; Ortea, J. J. Nat. Prod. 1993, 56, 1642.

https://doi.org/10.1021/np50099a033

29. Petrosino, T.; Riccieri, R.; Blasi, F.; Brutti, M.; D'Arco, G.; Bosi, A.; Maurelli, S.; Cossignani, L.; Simonetti, M. S.; Damiani, P. J. AOAC Int. 2007, 90, 1647.

30. Hancock, S. E.; Poad, B. L. J;. Batarseh, A.; Abbott, S. K.; Mitchell, T. W. Anal. Biochem. 2017, $524,45$. https://doi.org/10.1016/i.ab.2016.09.014

31. Standal, I. B.; Axelson, D. E.; Aursand, M. J. Am. Oil Chem. Soc. 2009, 86, 401. https://doi.org/10.1007/s11746-009-1370-y

32. Ruiz-Lopez, N.; Stubhaug, I.; Ipharraguerre, I.; Rimbach, G.; Menoyo, D. Mar. Drugs 2015, 13, 4255 https://doi.org/10.1007/s11746-009-1370-y

33. Molinari, F.; Valenti, M.; Potenza, D.; Dionisi, F.; Aragozzini, F. Ital. J. Food Sci. 1995, 1, 37.

34. Rosati, O.; Albrizio, S.; Montesano, D.; Riccieri, R.; Cossignani, L.; Curini, M.; Simonetti, M. S.; Rastrelli, L.; Damiani, P. J. Agric. Food Chem. 2007, 55, 191.

https://doi.org/10.1021/jf062221f

35. Tada, N.; Fujita, H.; Ando, Y. J. Am. Oil Chem. Soc. 2014, 91, 1131. https://doi.org/10.1007/s11746-014-2452-z

36. Aue, W. P.; Bartholdi, E.; Ernst, R. R. J. Chem. Phys. 1976, 64, 2229. https://doi.org/10.1063/1.432450

37. Nagayama, K.; Kumar, A.; Wüthrich, K.; Ernst, R. R. J. Magn. Reson. 1980, 40, 321. https://doi.org/10.1016/0022-2364(80)90255-3

38. Bax, A.; Summers, M. F. J. Am. Chem. Soc. 1986, 108, 2093-2094. https://doi.org/10.1021/ja00268a061

39. Bax, A.; Subramanian, S. J. Magn. Reson. 1986, 67, 565-570. https://doi.org/10.1016/0022-2364(86)90395-1 